Article

\title{
Hydrotreating of Jatropha-derived Bio-oil over Mesoporous Sulfide Catalysts to Produce Drop-in Transportation Fuels
}

\author{
Shih-Yuan Chen ${ }^{1, *} \mathbb{E}$, Takehisa Mochizuki ${ }^{1}$, Masayasu Nishi ${ }^{1}{ }^{(\mathbb{D}}$, Hideyuki Takagi $^{1}$, \\ Yuji Yoshimura ${ }^{1,2}$ and Makoto Toba ${ }^{1}$ \\ 1 Research Institute of Energy Frontier (RIEF), Department of Energy and Environment, National Institute of \\ Advanced Industrial Science and Technology (AIST), 16-1 Onogawa, Tsukuba, Ibaraki 305-8569, Japan; \\ t.mochizuki@aist.go.jp (T.M.); m.nishi@aist.go.jp (M.N.); hide-takagi@aist.go.jp (H.T.); \\ yuji.yos@ncr.nstda.or.th (Y.Y.); m.toba@aist.go.jp (M.T.) \\ 2 Materials for Energy Research Unit, National Metal and Materials Technology Center (MTEC), \\ Pahonyothin Rd. Klong 1, Klong Luang Pathumtani 12120, Thailand \\ * Correspondence: sy-chen@aist.go.jp; Tel.: +81-29-861-2680
}

Received: 29 March 2019; Accepted: 23 April 2019; Published: 26 April 2019

check for updates

\begin{abstract}
The bio-oil was largely produced by thermal pyrolysis of Jatropha-derived biomass wastes (denoted as Jatropha bio-oil) using a pilot plant with a capacity of $20 \mathrm{~kg} \mathrm{~h}^{-1}$ at Thailand Institute of Scientific and Technological Research (TISTR), Thailand. Jatropha bio-oil is an unconventional type of bio-oil, which is mostly composed of fatty acids, fatty acid methyl esters, fatty acid amides, and derivatives, and consequently, it contains large amounts of heteroatoms (oxygen $\sim 20 \mathrm{wt} . \%$, nitrogen $\sim 5$ wt.\%, sulfur 1000 ppm.). The heteroatoms, especially nitrogen, are highly poisonous to the metal or sulfide catalysts for upgrading of Jatropha bio-oil. To overcome this technical problem, we reported a stepwise strategy for hydrotreating of $100 \mathrm{wt}$ \% Jatropha bio-oil over mesoporous sulfide catalysts $\left(\mathrm{CoMo} / \gamma-\mathrm{Al}_{2} \mathrm{O}_{3}\right.$ and $\left.\mathrm{NiMo} / \gamma-\mathrm{Al}_{2} \mathrm{O}_{3}\right)$ to produce drop-in transport fuels, such as gasoline- and diesel-like fuels. This study is very different from our recent work on co-processing of Jatropha bio-oil (ca. $10 \mathrm{wt}$ \%) with petroleum distillates to produce a hydrotreated oil as a diesel-like fuel. Jatropha bio-oil was pre-treated through a slurry-type high-pressure reactor under severe conditions, resulting in a pre-treated Jatropha bio-oil with relatively low amounts of heteroatoms (oxygen $<20$ wt.\%, nitrogen $<2$ wt.\%, sulfur $<500 \mathrm{ppm}$.). The light and middle distillates of pre-hydrotreated Jatropha bio-oil were then separated by distillation at a temperature below $240{ }^{\circ} \mathrm{C}$, and a temperature of $240-360{ }^{\circ} \mathrm{C}$. Deep hydrotreating of light distillates over sulfide $\mathrm{CoMo} / \gamma-\mathrm{Al}_{2} \mathrm{O}_{3}$ catalyst was performed on a batch-type high-pressure reactor at $350{ }^{\circ} \mathrm{C}$ and $7 \mathrm{MPa}$ of $\mathrm{H}_{2}$ gas for $5 \mathrm{~h}$. The hydrotreated oil was a gasoline-like fuel, which contained 29.5 vol. $\%$ of $n$-paraffins, 14.4 vol. $\%$ of iso-paraffins, $4.5 \mathrm{vol} \%$ of olefins, $21.4 \mathrm{vol}$ \% of naphthene compounds and $29.6 \mathrm{wt}$ \% of aromatic compounds, and little amounts of heteroatoms (nearly no oxygen and sulfur, and less than 50 ppm of nitrogen), corresponding to an octane number of 44, and it would be suitable for blending with petro-gasoline. The hydrotreating of middle distillates over sulfide $\mathrm{NiMo} / \gamma-\mathrm{Al}_{2} \mathrm{O}_{3}$ catalyst using the same reaction condition produced a hydrotreating oil with diesel-like composition, low amounts of heteroatoms (no oxygen and less than 50 ppm of sulfur and nitrogen), and cetane number of 60, which would be suitable for use in drop-in diesel fuel.
\end{abstract}

Keywords: hydrotreating; mesoporous sulfide materials; waste Jatropha biomass; drop-in biofuels; upgrading technology 


\section{Introduction}

Biomass is one of the most abundant natural resources, which supplies around $10 \%$ of annual primary energy consumption corresponding to a capacity of 50 EJ globally in 2010 [1-3]. It is generally agreed that the chemicals and fuel with low carbon footprint can be synthesized by the conversion of biomass using various catalytic strategies, which contribute to the reduction of $\mathrm{CO}_{2}$ emission, and consequently, avert global warming [4-10]. For example, the biodiesel fuel (BDF), which is a so-called first-generation biofuel, can be synthesized by base-catalyzed transesterification of refined vegetable oils with methanol, and it has been extensively used in the transport sector, particularly in America, European Union and Association of South-East Asian Nations (ASEAN) counties [6,11-16]. However, it has caused a new environmental problem in waste biomass treatment, such as discarded kernel shells and husks, which are massively produced as byproducts in the BDF industry. Recent studies have focused on post-treatment and utilization of those biomass wastes into valuable products, such as gasification to produce syngas, liquification to produce chemicals and fuels, and chip production for thermal power generation $[7,17]$. Similar to biomass gasification and liquification, bio-oil can be synthesized by thermal conversion of biomass, especially the wastes, through the catalytic pyrolysis or non-catalytic pyrolysis technology, and therefore, it contains large amounts of heteroatom-containing hydrocarbons, oxygen, and especially sulfur, water and unwanted impurities which are highly associated with the feedstocks and the processing parameters used in the pyrolysis and condensation steps [18-21]. The subsequent upgrading of bio-oil through hydrotreating technology using metal catalysts, such as $\mathrm{Pd} / \mathrm{C}$, or sulfide catalysts, such as $\mathrm{Co}$ - or Ni-promoted $\mathrm{MoS}_{2} / \gamma-\mathrm{Al}_{2} \mathrm{O}_{3}$, is required to remove the heteroatoms, resulting in clean and drop-in biofuel with composition and fuel property closed to petro-fuels [22]. Unfortunately, the heteroatoms, water, and unwanted impurities, which are originally present in bio-oil, poison the active sites of metal and sulfide catalysts, causing serious catalyst deactivation, and consequently, reducing the quality of hydrotreated bio-oil [23-30]. Yoshimura et al. reported that the sulfide NiMo catalysts were deactivated by the oxygen-containing compounds due to the oxidation of active sites [23]. Laurent and Delmon showed that the deoxygenation of model compounds of bio-oils over CoMo and NiMo catalysts was strongly inhibited in the presence of water and ammonia [24]. There is still room for the development of innovative catalytic process using advanced catalysts with high resistance to heteroatoms, which can produce clean and drop-in fuel for direct formulating with petro-fuels.

Our recent study demonstrated that Jatropha bio-oil could be synthesized by thermal pyrolysis of waste Jatropha biomass (a mixture of kernel shell and husk) using a pilot plant with a capacity of ca. $20 \mathrm{~kg} / \mathrm{h}$ at Thailand Institute of Scientific and Technological Research (TISTR), Thailand [19]. The Jatropha bio-oil is an unconventional bio-oil with a high concentration of nitrogen (ca. $5 \mathrm{wt} \%$ ) and relatively low concentrations of oxygen (ca. $20 \mathrm{wt} \%$ ) and sulfur ( $<1000 \mathrm{ppm}$ ), which is mostly consisted of fatty acids, fatty acid methyl esters, fatty acid amides, and their derivatives ( $>50 \mathrm{wt} \%)$ in addition to other light organic compounds incorporated with heteroatoms. It is different from conventional bio-oils with high oxygen content (ca. 20-40 wt\%) and low sulfur and nitrogen contents $(<1 \mathrm{wt} \%)$, which were derived from cedar or pine biomass waste, and mostly consisted of carbohydrates and phenolic compounds. In the upgrading process, the upgrading catalysts, as aforementioned, were immediately deactivated by a high concentration of nitrogen-containing compounds when Jatropha bio-oil was directly used as a feedstock (Scheme 1a). To prevent catalyst deactivation, our previous study demonstrated a co-processing method for the upgrading of Jatropha bio-oil co-fed with petroleum distillates over sulfide CoMo and NiMo catalysts under severe conditions $\left(330-350{ }^{\circ} \mathrm{C}\right.$ and 5-7 $\mathrm{MPa}$ of $\mathrm{H}_{2}$ ) [30]. The diesel-like fuel with nearly no heteroatoms (sulfur, oxygen, and nitrogen $<10 \mathrm{ppm}$ ) could be obtained by hydrotreating of oil feedstock containing ca. $10 \mathrm{wt} \%$ of Jatropha bio-oil and ca. $90 \mathrm{wt} \%$ of light gas oil. In this study, a stepwise strategy was reported for hydrotreating of $100 \mathrm{wt} \%$ Jatropha bio-oil over sulfide catalysts to produce drop-in transport fuels including gasolineand diesel-like fuels (Scheme $1 \mathrm{~b}$ ). The Jatropha bio-oil was pre-treated by a slurry bed reactor at $400{ }^{\circ} \mathrm{C}$ and $7 \mathrm{MPa}$ of $\mathrm{H}_{2}$ using waste $\mathrm{NiMo} / \gamma-\mathrm{Al}_{2} \mathrm{O}_{3}$ catalyst, followed by distillation. The clean 
and drop-in transport fuels were then obtained by hydrotreating of pre-treated distillates over fresh $\mathrm{CoMo} / \gamma-\mathrm{Al}_{2} \mathrm{O}_{3}$ or $\mathrm{NiMo} / \gamma-\mathrm{Al}_{2} \mathrm{O}_{3}$ catalysts using a high-pressure stainless-steel batch-type reactor under severe conditions. The influence of catalysts and the processing parameters of the composition and fuel property of upgraded Jatropha bio-oils were reported.

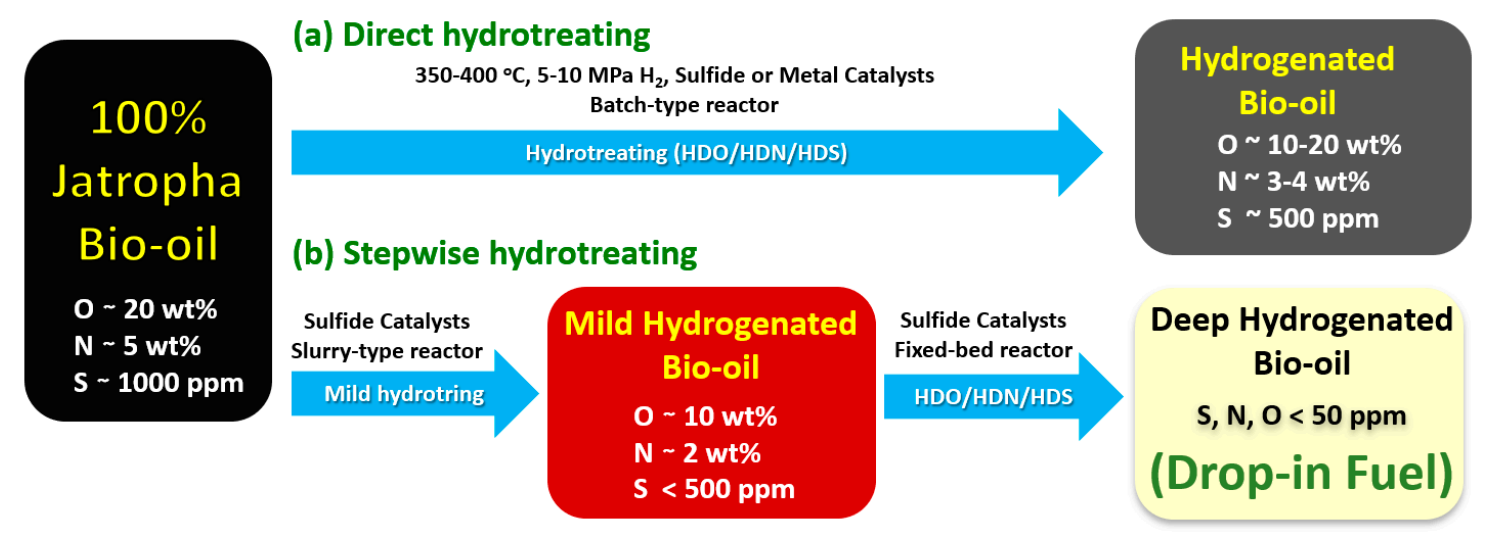

Scheme 1. (a) direct hydrotreating and (b) stepwise hydrotreating of the unconventional Jatropha bio-oil.

\section{Results}

The sulfide $\mathrm{CoMo} / \gamma-\mathrm{Al}_{2} \mathrm{O}_{3}$ or $\mathrm{NiMo} / \gamma-\mathrm{Al}_{2} \mathrm{O}_{3}$ catalysts were prepared by the same procedures as reported in our previous study [30], and their structural properties were completely studied by X-ray diffraction and absorption techniques, physisorption and chemisorption, and electron microscopes [30-33]. It has found that the sulfide $\mathrm{CoMo} / \gamma-\mathrm{Al}_{2} \mathrm{O}_{3}$ catalyst with relatively large amounts of acidic sites $\left(\mathrm{NH}_{3}\right.$ uptake $\left.=0.92 \mathrm{mmol} \mathrm{g}^{-1}\right)$ and coordinatively unsaturated sites (NO uptake $=0.11 \mathrm{mmol} \mathrm{g}^{-1}$ ) was associated with small Co-incorporated $\mathrm{MoS}_{2}$-like slabs $(4.5 \pm 1.2 \mathrm{~nm}$ in length and $2.0 \pm 0.53 \mathrm{~nm}$ in height) with a relatively high stacking number $(3.8 \pm 0.86)$ on the mesoporous alumina material. In contrast, the sulfide $\mathrm{NiMo} / \gamma-\mathrm{Al}_{2} \mathrm{O}_{3}$ catalyst with relatively small amounts of acidic sites $\left(\mathrm{NH}_{3}\right.$ uptake $=0.77 \mathrm{mmol} \mathrm{g}^{-1}$ ) and coordinatively unsaturated sites ( $\mathrm{NO}$ uptake $=0.093 \mathrm{mmol} \mathrm{g}^{-1}$ ) was presumably due to large Ni-incorporated $\mathrm{MoS}_{2}$-like slabs $(5.9 \pm 1.2 \mathrm{~nm}$ in length and $1.5 \pm 0.53 \mathrm{~nm}$ in height) with a relatively low stacking number $(2.6 \pm 0.71)$ on the mesoporous alumina material. In this study, the structural properties of sulfide $\mathrm{CoMo} / \gamma-\mathrm{Al}_{2} \mathrm{O}_{3}$ or $\mathrm{NiMo} / \gamma-\mathrm{Al}_{2} \mathrm{O}_{3}$ catalysts were examined again by the wide-angle XRD pattern (Figure 1A), nitrogen physisorption (Figure 1B), and high-resolution transmission electron microscope (HRTEM) images (Figure 2), in comparison to those of $\gamma-\mathrm{Al}_{2} \mathrm{O}_{3}$ as a supporting material. The XRD study shows that two diffraction peaks of Co- or Ni-incorporated $\mathrm{MoS}_{2}$-slabs are hardly observed at $2 \theta \sim 33^{\circ}$ and $59^{\circ}$, indicating that their sizes are smaller than $5 \mathrm{~nm}$, and the diffraction peaks of the mesoporous $\gamma-\mathrm{Al}_{2} \mathrm{O}_{3}$ framework are weakened by the impregnating. The $\mathrm{N}_{2}$ physisorption study shows that the $\mathrm{H}_{1}$ hysteresis loops of the type IV isotherms are reduced by the impregnation of $\mathrm{Co}$ - or Ni-incorporated $\mathrm{MoS}_{2}$-slabs on the mesoporous $\gamma-\mathrm{Al}_{2} \mathrm{O}_{3}$ framework. The nitrogen physisorption study shows that the supporting material of $\gamma-\mathrm{Al}_{2} \mathrm{O}_{3}$ has a surface area of $206 \mathrm{~m}^{2} \mathrm{~g}^{-1}$, a pore volume of $0.68 \mathrm{~cm}^{3} \mathrm{~g}^{-1}$ and pore size of $12 \mathrm{~nm}$. The sulfide $\mathrm{CoMo} / \gamma-\mathrm{Al}_{2} \mathrm{O}_{3}$ or $\mathrm{NiMo} / \gamma-\mathrm{Al}_{2} \mathrm{O}_{3}$ catalysts have surface areas of $204-205 \mathrm{~m}^{2} \mathrm{~g}^{-1}$ and pore sizes of $12 \mathrm{~nm}$, which are close to those of $\gamma-\mathrm{Al}_{2} \mathrm{O}_{3}$ supporting material, whereas their pore volumes are decreased to $0.38-0.41 \mathrm{~cm}^{3} \mathrm{~g}^{-1}$. It indicates that the Co- and Ni-incorporated $\mathrm{MoS}_{2}$-slabs were impregnated inside the pores of the mesoporous $\gamma-\mathrm{Al}_{2} \mathrm{O}_{3}$ framework. The HRTEM images clearly show that the sulfide $\mathrm{CoMo} / \gamma-\mathrm{Al}_{2} \mathrm{O}_{3}$ or $\mathrm{NiMo} / \gamma-\mathrm{Al}_{2} \mathrm{O}_{3}$ catalysts are composed of the Co- or Ni-incorporated $\mathrm{MoS}_{2}$-slabs and the mesostructured $\gamma-\mathrm{Al}_{2} \mathrm{O}_{3}$ particles. These results suggest that the sulfide $\mathrm{CoMo} / \gamma-\mathrm{Al}_{2} \mathrm{O}_{3}$ or $\mathrm{NiMo} / \gamma-\mathrm{Al}_{2} \mathrm{O}_{3}$ catalysts with well-dispersed $\mathrm{Co}$ - and Ni-incorporated $\mathrm{MoS}_{2}$-slabs on the mesoporous $\gamma-\mathrm{Al}_{2} \mathrm{O}_{3}$ framework were successfully prepared. 
Jatropha bio-oil was largely produced by fast pyrolysis of waste Jatropha biomass at $500{ }^{\circ} \mathrm{C}$ using a pilot plant equipped with an electrostatic precipitator [19]. The yields of Jatropha bio-oil, water-soluble phase and gases were 21.3, 28.6, and $50.1 \mathrm{wt} \%$, respectively. Conventional bio-oil.
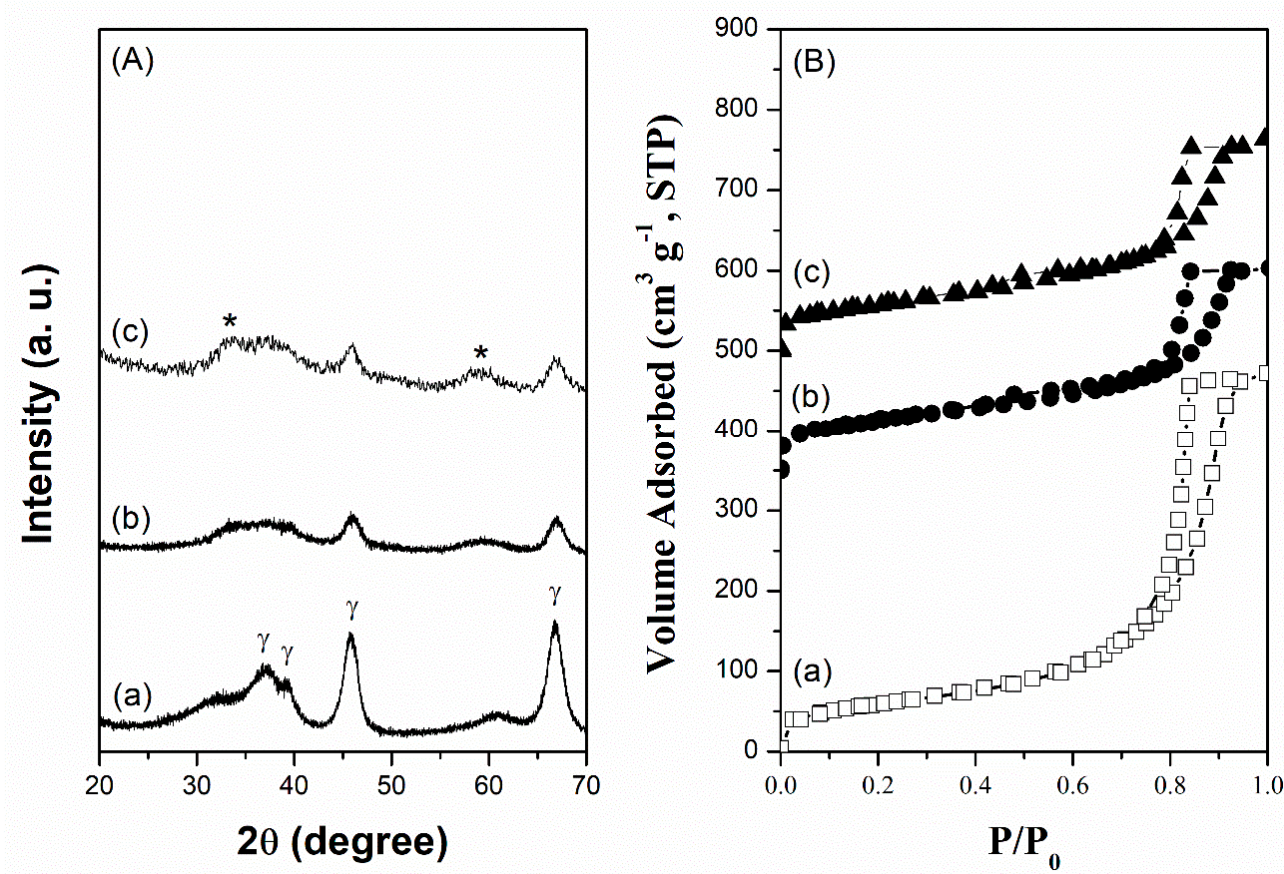

Figure 1. (A) powered XRD patterns, (B) $\mathrm{N}_{2}$ adsorption-desorption isotherms of mesoporous sulfide catalysts: (b) $\mathrm{CoMo} / \gamma-\mathrm{Al}_{2} \mathrm{O}_{3}$, and (c) $\mathrm{NiMo} / \gamma-\mathrm{Al}_{2} \mathrm{O}_{3}$ catalysts, in comparison to those of a supporting material: (a) $\gamma-\mathrm{Al}_{2} \mathrm{O}_{3}$. The asterisk and gamma $(\gamma)$ represent the characteristic peaks of Co-incorporated $\mathrm{MoS}_{2}$-like slabs (or Ni-incorporated counterpart) and gamma-alumina framework, respectively.
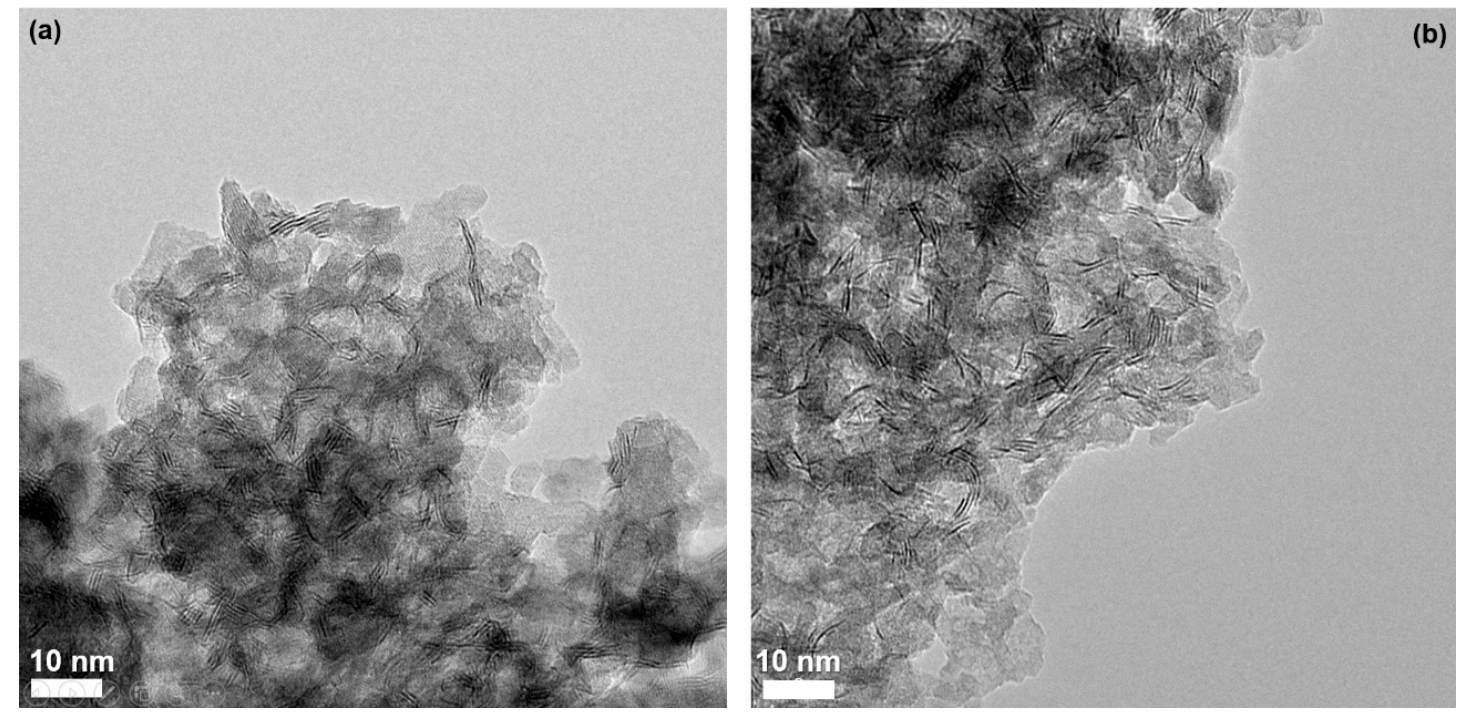

Figure 2. High-resolution transmission electron microscope (HRTEM) images of mesoporous sulfide catalysts: (a) $\mathrm{CoMo} / \gamma-\mathrm{Al}_{2} \mathrm{O}_{3}$ and (b) $\mathrm{NiMo} / \gamma-\mathrm{Al}_{2} \mathrm{O}_{3}$.

Derived by fast pyrolysis of cedar or pine, biomass is mostly composed of lignin-derived phenolic compounds, and it consequently contains a high concentration of oxygen ( $>30 \mathrm{wt} \%)$ and low concentrations of sulfur (ca. $50 \mathrm{ppm}$ ) and nitrogen (ca. $0.1 \mathrm{wt} \%$ ) [19,20]. However, Jatropha bio-oil is mostly composed of fatty acids, fatty acid methyl esters, fatty acid amides and derivatives, presumably due to that Jatropha oil is partly remained in the waste Jatropha biomass after the oil extraction. 
As a result, Jatropha bio-oil contains a high concentration of nitrogen (ca. $5 \mathrm{wt} \%$ ), a relatively high concentration of sulfur (ca. $1000 \mathrm{ppm}$ ) and a relatively low concentration of oxygen (ca. $20 \mathrm{wt} \%$ ).

The heteroatoms, especially nitrogen, are extremely poisonous to metal and sulfide catalysts used in the upgrading process. In Scheme 1a, the preliminary studies showed that direct hydrotreating of Jatropha bio-oil over sulfide and metal catalysts produced low-quality hydrotreated bio-oils with high heteroatoms, which was inapplicable for use in fuel oil blending, even if the severe conditions were used. In other words, the sulfide and metal catalysts were immediately deactivated by strong adsorption of heteroatoms on the catalytically active sites, especially nitrogen, in the upgrading process. To solve this technical problem, we proposed a stepwise strategy for the upgrading of Jatropha bio-oil over sulfide catalysts to produce drop-in biofuels (see Scheme $1 \mathrm{~b}$ and Figure 3). Jatropha bio-oil was pre-treated through a slurry-type high pressure reactor at $400{ }^{\circ} \mathrm{C}$ and $7 \mathrm{MPa}$ of $\mathrm{H}_{2}$ for $2 \mathrm{~h}$ using $1 \mathrm{wt} \%$ of waste NiMo catalyst, resulting in a pre-treated Jatropha bio-oil with relatively low concentrations of heteroatoms (oxygen $<20 \mathrm{wt} . \%$, nitrogen $<2 \mathrm{wt} . \%$, sulfur $<500 \mathrm{ppm}$.). The yield of pre-treated Jatropha bio-oil was around $65 \%$. The pre-treated bio-oil was then divided into three fractions through distillation: (a) light distillates $\left(21.0 \%\right.$, distillation temperature $\left.\left(\mathrm{T}_{\mathrm{d}}\right)<240^{\circ} \mathrm{C}\right)$, (ii) middle distillates $\left(59.3 \%, \mathrm{~T}_{\mathrm{d}}=240-360^{\circ} \mathrm{C}\right)$ and (iii) heavy distillates $\left(19.7 \%, \mathrm{~T}_{\mathrm{d}}>360^{\circ} \mathrm{C}\right)$. We focused on deep hydrotreating of light distillates, whose composition was closed to gasoline, over sulfide $\mathrm{CoMo} / \gamma-\mathrm{Al}_{2} \mathrm{O}_{3}$ catalyst (Figure $3 \mathrm{a}$ ) and deep hydrotreating of middle distillates, whose composition was closed to diesel, over $\mathrm{NiMo} / \gamma-\mathrm{Al}_{2} \mathrm{O}_{3}$ catalyst (Figure $3 \mathrm{~b}$ ). The results were discussed hereafter.

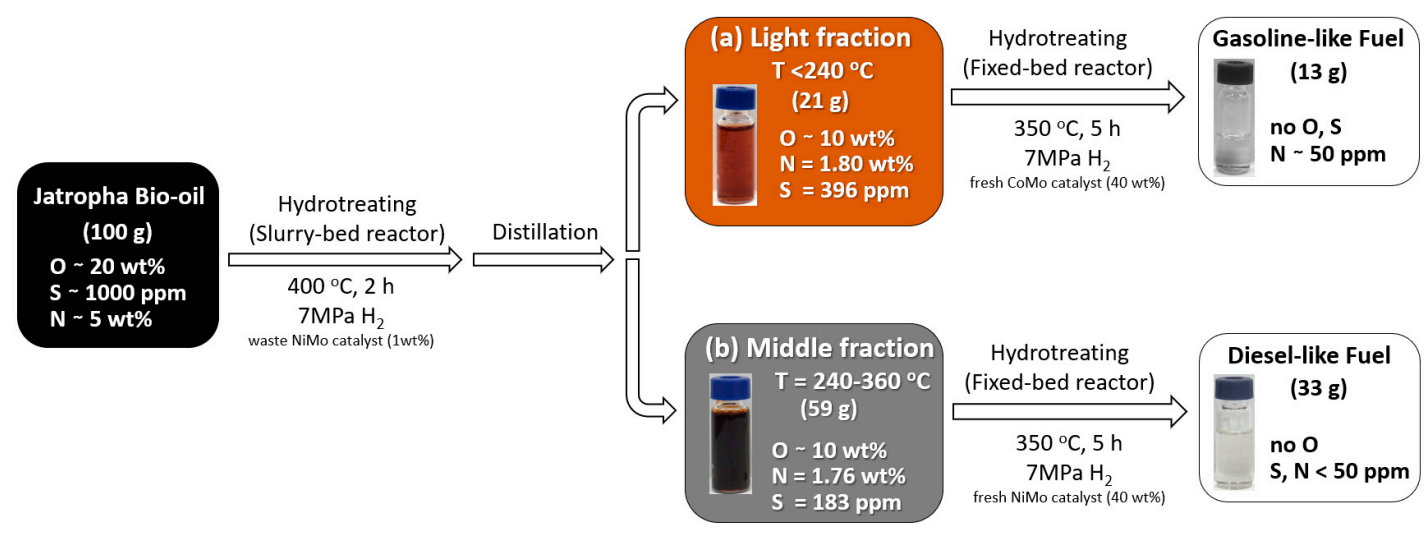

Figure 3. Stepwise hydrotreating of Jatropha bio-oil over sulfide catalysts to produce gasoline-like and diesel-like fuels (a) light fraction was obtained at the distillation temperature equal to or smaller than $240{ }^{\circ} \mathrm{C}$ under $75 \mathrm{mmHg}$; (b) middle fraction was obtained at the distillation temperature between 240 and $360^{\circ} \mathrm{C}$.

Deep hydrotreating of light distillates over the sulfide $\mathrm{CoMo} / \gamma-\mathrm{Al}_{2} \mathrm{O}_{3}$ catalyst was performed on a stainless-steel batch-type reactor at $350{ }^{\circ} \mathrm{C}$ and $7 \mathrm{MPa}$ of $\mathrm{H}_{2}$ for $5 \mathrm{~h}$ (Figure 3a). The hydrotreating oil was characterized by gas chromatography instrument equipped with a flame ionization detector (GC-FID) and elemental analysis. Figure 4 shows that the hydrotreating oil is a gasoline-like fuel, except a small portion of paraffins with carbon number higher than 10, corresponding to jet/diesel fuel range compounds. Table 1 shows that the hydrotreated oil contains 29.5 vol. $\%$ of $n$-paraffins, $14.4 \mathrm{vol} . \%$ of iso-paraffins, $4.5 \mathrm{vol} \%$ of olefins, $21.4 \mathrm{vol} . \%$ of naphthene compounds, $29.6 \mathrm{wt} . \%$ of aromatic compounds and little amounts of heteroatoms (nearly no oxygen and sulfur, and ca. $50 \mathrm{ppm}$ of nitrogen), corresponding to an octane number of 44 . This result suggests that the hydrotreating oil would be suitable for blending with petro-gasoline. On the other hand, the paraffins with carbon number higher than 10 can be separated from the hydrotreating oil by further distillation, and it would be suitable for use in jet/diesel fuel [34]. 
Table 1. The elemental analysis, composition and octane number of gasoline-like fuel a .

\begin{tabular}{|c|c|c|c|c|c|c|c|c|c|c|}
\hline Samples & $\begin{array}{c}\mathrm{S} \\
(\mathrm{ppm})\end{array}$ & $\begin{array}{c}\mathrm{N} \\
(\mathrm{ppm})\end{array}$ & $\begin{array}{c}\text { Octane } \\
\text { Number }\end{array}$ & $\mathrm{H} / \mathrm{C}$ & $\begin{array}{l}\text { Density } \\
\left(\mathrm{g} / \mathrm{cm}^{3}\right)\end{array}$ & $\begin{array}{c}\text { n-Paraffin } \\
\text { (vol.\%) }\end{array}$ & $\begin{array}{c}\text { iso-Paraffin } \\
\text { (vol.\%) }\end{array}$ & $\begin{array}{l}\text { Olefin } \\
\text { (vol.\%) }\end{array}$ & $\begin{array}{l}\text { Naphthene } \\
\text { (vol.\%) }\end{array}$ & $\begin{array}{c}\text { Aromatic } \\
\text { (vol.\%) }\end{array}$ \\
\hline This work & 0 & 49 & 44.5 & 1.77 & 0.71 & 29.5 & 14.4 & 4.99 & 21.4 & 29.6 \\
\hline Gasoline ${ }^{b}$ & $\max .10$ & - & $\min .89$ & - & $\max .0 .783$ & - & - & - & - & $\min .1^{\mathrm{c}}$ \\
\hline
\end{tabular}

a Synthesized by stepwise hydrogenation of Jatropha bio-oil over sulfide $\mathrm{CoMo} / \gamma-\mathrm{Al}_{2} \mathrm{O}_{3}$ catalysts. The reaction condition for deep hydrogenation (Scheme $1 \mathrm{~b}$ and Figure $3 \mathrm{a}$ ): $350{ }^{\circ} \mathrm{C}, 5 \mathrm{~h}, 2 \mathrm{~g}$ of sulfided $\mathrm{CoMo} / \gamma-\mathrm{Al}_{2} \mathrm{O}_{3}$ catalyst, $5 \mathrm{~g}$ of light distillate obtained by distillation of pre-treated Jatropha bio-oil at the temperature lower than $240{ }^{\circ} \mathrm{C}$. The yield was $60 \pm 5 \mathrm{wt} . \%$.

${ }^{b}$ Based on the Japanese fuel standard JIS K2202:2012. ${ }^{c}$ Benzene is specified to less than $1 \mathrm{vol} \%$ in gasoline.

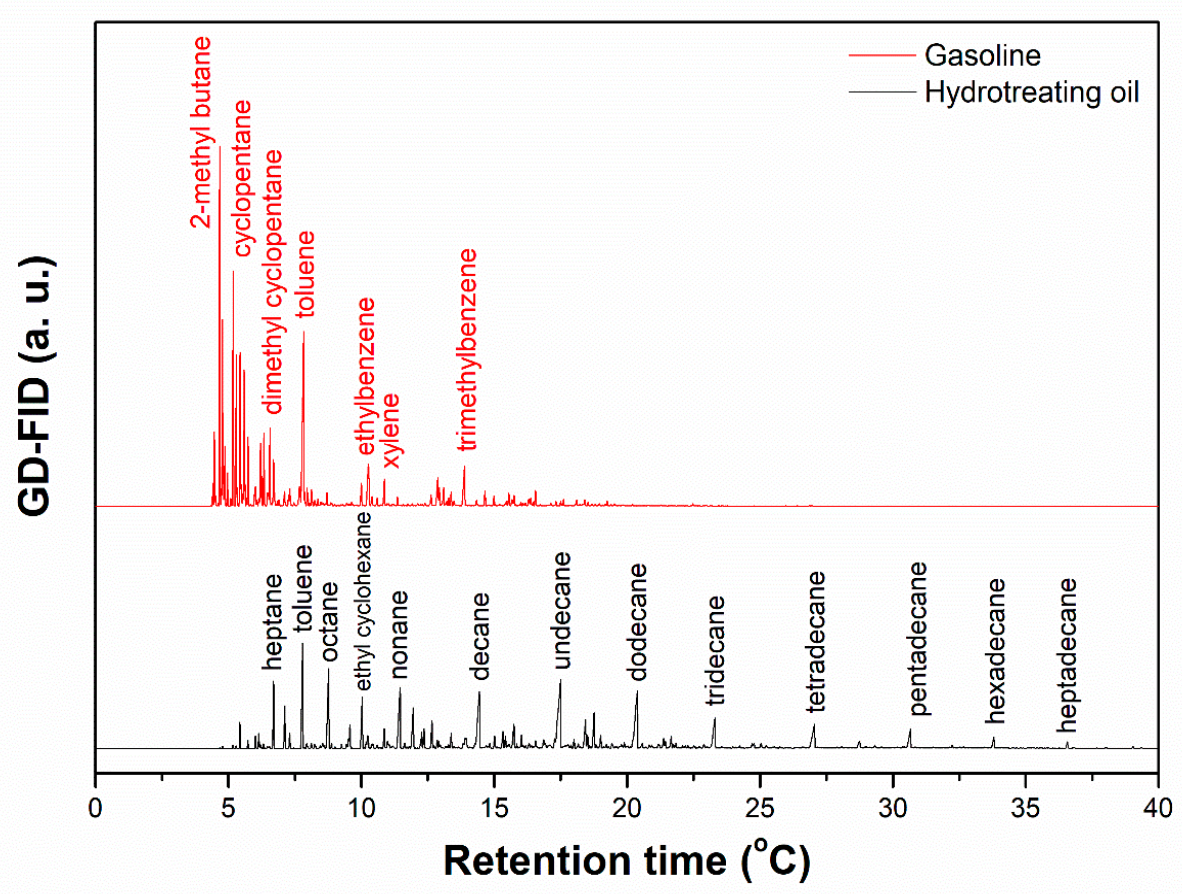

Figure 4. GC-FID profiles of gasoline and hydrotreating oil, which is produced by deep hydrotreating of light distillates over sulfide $\mathrm{CoMo} / \gamma-\mathrm{Al}_{2} \mathrm{O}_{3}$ catalyst at $350{ }^{\circ} \mathrm{C}$ and $7 \mathrm{MPa}$ of $\mathrm{H}_{2}$ for $5 \mathrm{~h}$.

Deep hydrotreating of middle distillates over sulfide $\mathrm{NiMo} / \gamma-\mathrm{Al}_{2} \mathrm{O}_{3}$ catalyst was performed by a large-scale batch-type high pressure reactor under the same reaction condition. (Figure $3 b$ ). In a typical synthesis, $100 \mathrm{~g}$ of middle distillates were mixed with $40 \mathrm{~g}$ of sulfide $\mathrm{NiMo} / \gamma-\mathrm{Al}_{2} \mathrm{O}_{3}$ catalyst under an atmosphere of $\mathrm{H}_{2}$, followed by heating to $350{ }^{\circ} \mathrm{C}$ in $1 \mathrm{~h}$ under a pressured atmosphere of $\mathrm{H}_{2}$ (7 MPa) and vigorously stirring. After $350{ }^{\circ} \mathrm{C}$ for $5 \mathrm{~h}$, the hydrotreating oil was cooled to ambient condition and corrected by filtration. The yield of hydrotreating oil was $55.2 \%$. The sulfur and nitrogen concentrations of hydrotreating oil were smaller than 10 and 50 ppm, respectively. In Figure 5, the GC analysis equipped with FID and mass detectors indicates that the composition of hydrotreating oil, produced by deep hydrotreating of middle distillates over sulfide $\mathrm{NiMo} / \gamma-\mathrm{Al}_{2} \mathrm{O}_{3}$ catalyst, is similar to that of petro-diesel. The distillation curve of hydrotreating oil was analyzed by the procedures of JIS K2254 method (Figure 6). The results show that the temperatures for initial distillation, $50 \mathrm{vol} \%$ fraction and 95 vol.\% fraction of hydrotreating oil are 116, 289, and $355{ }^{\circ} \mathrm{C}$, respectively. According to the procedures of JIS K2249 and K2280-5 methods [35,36], the density and cetane number of hydrotreating oil are $0.8252 \mathrm{~g} \mathrm{~cm}^{-3}$ and 60.8 , respectively. The fuel property of hydrotreating oil can meet with the international fuel standard. It indicates that the hydrotreating oil produced by deep hydrotreating of middle distillates over $\mathrm{NiMo} / \gamma-\mathrm{Al}_{2} \mathrm{O}_{3}$ catalyst is a clean and drop-in diesel-like biofuel, which can be applicable for use in high blends. 


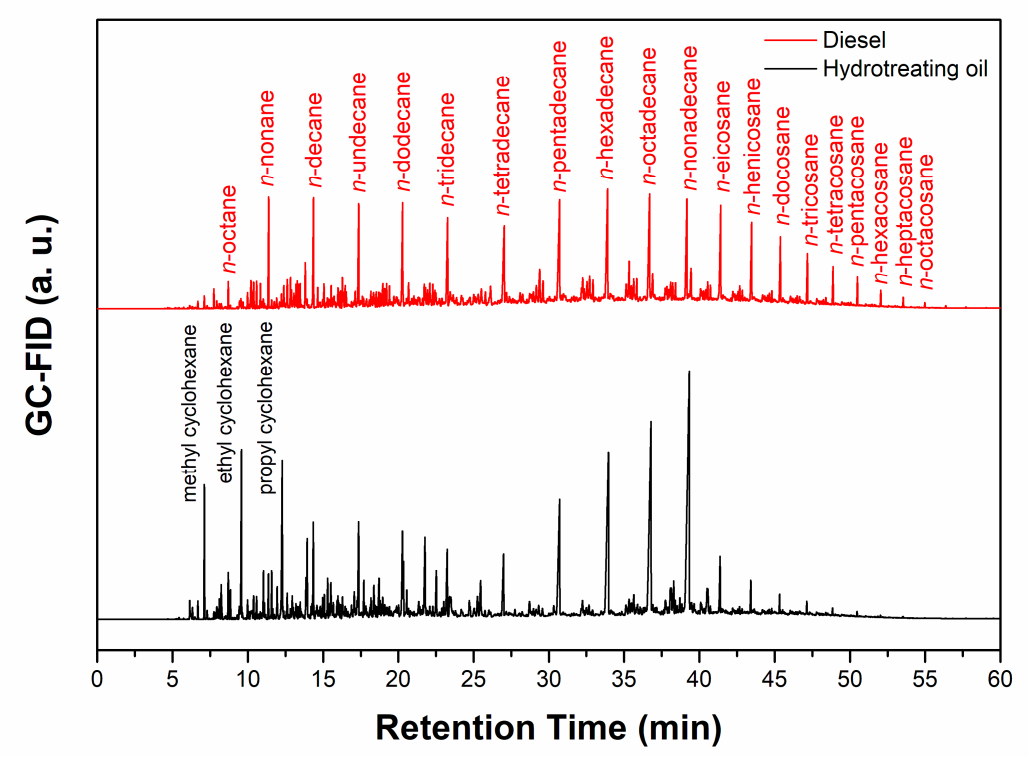

Figure 5. GC profiles of diesel and hydrotreating oil, which is produced by deep hydrotreating of middle distillates over sulfide $\mathrm{NiMo} / \gamma-\mathrm{Al}_{2} \mathrm{O}_{3}$ catalyst at $350{ }^{\circ} \mathrm{C}$ and $7 \mathrm{MPa}$ of $\mathrm{H}_{2}$ for $5 \mathrm{~h}$.

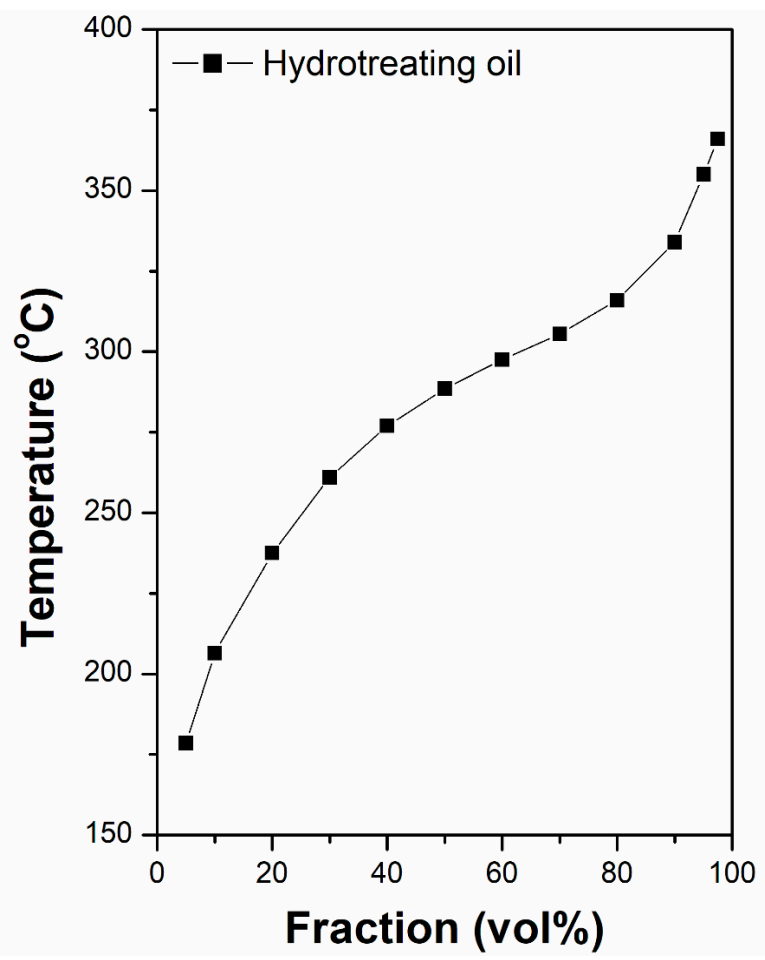

Figure 6. Distillation curve of hydrotreating oil, which is produced by deep hydrotreating of middle distillates over sulfide $\mathrm{NiMo} / \gamma-\mathrm{Al}_{2} \mathrm{O}_{3}$ catalyst at $350{ }^{\circ} \mathrm{C}$ and $7 \mathrm{MPa}$ of $\mathrm{H}_{2}$ for $5 \mathrm{~h}$.

\section{Material and Methods}

\subsection{Preparation and Characterization of Sulfide Catalysts}

The sulfide catalysts were prepared by incipient impregnation method. The cobalt- and nickel-promoted molybdenum aqueous solutions (denoted by $\mathrm{CoMo}$ (cit) and $\mathrm{NiMo(cit),} \mathrm{respectively)}$ were freshly prepared by the procedures as described in our previous study [30]. For the preparation of freshly prepared $\mathrm{CoMo}(\mathrm{cit})$ and $\mathrm{NiMo}(\mathrm{cit})$ aqueous solution, the molybdenum oxide (Wako) was 
dispersed in hot deionized water (ca. $90^{\circ} \mathrm{C}$ ) for $12 \mathrm{~h}$ under stirring. Cobalt nitrate (or nickel nitrate) and citric acid were slowly added to this solution under heating and stirring conditions, resulting in freshly prepared $\mathrm{CoMo}$ (cit) or $\mathrm{NiMo}$ (cit) aqueous solution with a molar composition of $1 \mathrm{MoO}_{3}$ : $0.5 \mathrm{CoO}$ (or NiO): $0.58 \mathrm{C}_{6} \mathrm{H}_{8} \mathrm{O}_{7}: 1.67 \mathrm{H}_{2} \mathrm{O}$. The extruded $\gamma-\mathrm{Al}_{2} \mathrm{O}_{3}$ particles as the supporting materials were dried at $120{ }^{\circ} \mathrm{C}$ for $6 \mathrm{~h}$ prior to the impregnation. For the preparation of sulfide catalysts, the $\mathrm{CoMo}$ (cit) and $\mathrm{NiMo}(\mathrm{cit})$ aqueous solutions were slowly dropped on the extruded $\gamma-\mathrm{Al}_{2} \mathrm{O}_{3}$ sample under low vacuum (ca. 0.1 torr). The as-made $\mathrm{CoMo}$ (cit) and $\mathrm{NiMo(cit)-impregnated} \gamma-\mathrm{Al}_{2} \mathrm{O}_{3}$ samples were aged at the room temperature for $1 \mathrm{~h}$ under vacuum, followed by drying through microwave irradiation $\left(1050 \mathrm{~W}, 10 \mathrm{~Hz}\right.$ ) for $10 \mathrm{~min}$. The $\mathrm{CoO}$ (or $\mathrm{NiO}$ ) and $\mathrm{MoO}_{3}$ loadings were $6.1 \mathrm{wt} . \%$ and $23.6 \mathrm{wt} . \%$, respectively. The sulfidation was carried out in a quartz tube reactor using a $5 \mathrm{vol} \% \mathrm{H}_{2} \mathrm{~S} / \mathrm{H}_{2}$ standard gas at $360^{\circ} \mathrm{C}$ for $6 \mathrm{~h}$. As a result, the sulfide $\mathrm{CoMo} / \mathrm{Al}_{2} \mathrm{O}_{3}$ and $\mathrm{NiMo} / \mathrm{Al}_{2} \mathrm{O}_{3}$ catalysts could be prepared. Characterizations were performed by XRD using a Rigaku Miniflex diffractometer (Akishima, Tokyo, Japan), $\mathrm{N}_{2}$ physisorption using a Belsorp instrument (Osaka, Japan) and HRTEM determined by a TOPCON EM002B instrument (Itabashi-ku, Tokyo, Japan) [30].

\subsection{Stepwise Hydrotreating of Jatropha Bio-Oil}

Jatropha bio-oil produced by thermal pyrolysis of waste Jatropha biomass was kindly supplied by TISTR, Thailand, using a pilot plant with a capacity of $20 \mathrm{Kg} / \mathrm{h}$. The elemental analysis and composition of Jatropha residue were reported in the previous research [20]. The Jatropha derived bio-oil was corrected using an electrostatic precipitator after the condensation of the water phase $[19,20]$. The elemental and water analyses showed that Jatropha bio-oil contained $3.2 \mathrm{wt} . \%$ of water and $96.8 \mathrm{wt} . \%$ of heteroatom-containing hydrocarbon, whose composition was $66.5 \mathrm{wt} . \%$ of carbon, $8.80 \mathrm{wt} . \%$ of hydrogen, and $5.82 \mathrm{wt} . \%$ of nitrogen and $18.9 \mathrm{wt} . \%$ of oxygen. Scheme $1 \mathrm{~b}$ shows a stepwise strategy for the upgrading of Jatropha bio-oil over sulfide catalysts under severe conditions. To reduce viscosity and partly deoxygenation, the pre-treatment of Jatropha bio-oil was performed in a slurry bed reactor using waste sulfide $\mathrm{NiMo} / \gamma-\mathrm{Al}_{2} \mathrm{O}_{3}$ catalyst $(1 \mathrm{wt} . \%)$ at $400{ }^{\circ} \mathrm{C}$ and $7 \mathrm{MPa}$ of $\mathrm{H}_{2}$ for $2 \mathrm{~h}$ [37]. The pre-treated Jatropha bio-oil was distilled and separated into three fractions: (i) light distillates $\left(<240^{\circ} \mathrm{C}\right)$, (ii) middle distillates $\left(240-360^{\circ} \mathrm{C}\right)$ and (iii) heavy distillates $\left(>360^{\circ} \mathrm{C}\right)$ using a glass-type distillation instrument under vacuum $(75 \mathrm{mmHg})$. The light and middle distillates can be classified as gasoline- and diesel-like compounds, which were corresponded to the compounds with boiling points of less than $160{ }^{\circ} \mathrm{C}$ and $160-280{ }^{\circ} \mathrm{C}$ under atmospheric pressure, respectively. The yield of light distillates which composition was closed to gasoline was $21 \mathrm{wt} . \%$, and that of middle distillates which composition was closed to diesel was around $59 \mathrm{wt} . \%$., In this study, we focused on the deep hydrotreating of light and middle distillates over sulfide $\mathrm{CoMo} / \gamma-\mathrm{Al}_{2} \mathrm{O}_{3}$ or $\mathrm{NiMo} / \gamma-\mathrm{Al}_{2} \mathrm{O}_{3}$ catalysts into clean and drop-in biofuels (Figure 3). The deep hydrotreating was performed on a high-pressure stainless-steel batch-type reactor at $350{ }^{\circ} \mathrm{C}$ and $7 \mathrm{MPa}$ of $\mathrm{H}_{2}$ for $5 \mathrm{~h}$ using a catalyst/oil weight ratio of 0.4. The hydrotreated oils were analyzed by Agilent 6890 GC-FID (Santa Clara, CA, USA) instrument equipped with a mass detector, elemental analysis of carbon, nitrogen, hydrogen, sulfur, and the fuel property.

\section{Conclusions}

Jatropha bio-oil was mostly composed of fatty acids, fatty acid methyl esters, fatty acid amides, and derivatives, corresponding to high concentrations of heteroatoms, especially nitrogen. To overcome the catalyst deactivation by those heteroatoms, we had developed a stepwise strategy for hydrotreating of $100 \mathrm{wt} . \%$ Jatropha bio-oil over sulfide catalysts to produce clean and drop-in transport biofuels, such as gasoline- and diesel-like biofuels. This stepwise strategy included (i) pre-treatment of Jatropha bio-oil over waste $\mathrm{NiMo} / \gamma-\mathrm{Al}_{2} \mathrm{O}_{3}$ catalyst $(1 \mathrm{wt} . \%)$ using a slurry-type reactor under severe conditions $\left(400^{\circ} \mathrm{C}\right.$, $7 \mathrm{MPa}$ of $\mathrm{H}_{2}, 2 \mathrm{~h}$ ), (ii) distillation of pre-treated Jatropha bio-oil into light distillates $\left(\mathrm{T}_{\mathrm{d}}<240{ }^{\circ} \mathrm{C}\right.$ ) and middle distillates $\left(\mathrm{T}_{\mathrm{d}}=240-360^{\circ} \mathrm{C}\right.$ ), (iii) deep hydrotreating of light and middle distillates over sulfide $\mathrm{CoMo} / \gamma-\mathrm{Al}_{2} \mathrm{O}_{3}$ and $\mathrm{NiMo} / \gamma-\mathrm{Al}_{2} \mathrm{O}_{3}$ catalysts (40 wt.\%) using a batch-type reactor under severe 
conditions $\left(350{ }^{\circ} \mathrm{C}, 7 \mathrm{MPa}\right.$ of $\mathrm{H}_{2}, 5 \mathrm{~h}$ ) to produce clean and drop-in biofuels. Among the step (iii), we found that the hydrotreating oil with gasoline-like composition and an octane number of 44 could be synthesized by deep hydrotreating of light distillates over sulfide $\mathrm{CoMo} / \gamma-\mathrm{Al}_{2} \mathrm{O}_{3}$ catalyst, and it would be suitable for partly blending with petro-gasoline. On the other hand, the hydrotreating oil with diesel-like composition and a cetane number of 60.8 could be produced by deep hydrotreating of middle distillates over sulfide $\mathrm{NiMo} / \gamma-\mathrm{Al}_{2} \mathrm{O}_{3}$ catalyst, and it would be suitable for use in diesel engine directly. Moreover, the waste $\mathrm{NiMo} / \gamma-\mathrm{Al}_{2} \mathrm{O}_{3}$ catalyst could be recycled and used again in the step (i) of this stepwise hydrotreatment, which significantly reduced the environmental pollution and production cost for eco-cost and environmentally friendly production of biofuel.

Author Contributions: S.-Y.C. conceived, designed and performed the experiments; M.N. assisted in manuscript editing; T.M., H.T., M.T., and Y.Y. provided suggestions; S.-Y.C. wrote the paper.

Funding: This research was partly funded by Japan Science and Technology Agency (JST)/Japan International Cooperation Agency (JICA) and the Science and Technology Research Partnership for Sustainable Development (SATREPS).

Acknowledgments: The authors would like to thank Suzuki Yoshizo and Sugimoto Yoshikazu of RIEF, AIST, and Thanes Utistham, Yoothana Thanmongkhon, and Wirachai Soontornrangson of the Energy Technology Department, Thailand Institute of Scientific and Technological Research (TISTR) for their kind assistance in the production and pretreatment of Jatropha bio-oil.

Conflicts of Interest: The authors declare no conflict of interest.

\section{References}

1. Kohl, M.; Neupane, P.R.; Lotfiomran, N. The impact of tree age on biomass growth and carbon accumulation capacity: A retrospective analysis using tree ring data of three tropical tree species grown in natural forests of Suriname. PLoS ONE 2017, 12, e0181187. [CrossRef]

2. 2010 Survey of Energy Resources. World Energy Council. Available online: https://www.worldenergy.org/ wp-content/uploads/2012/09/ser_2010_report_1.pdf (accessed on 26 November 2010).

3. Biomass First Results from an Integrated Assessment; Production, Supply, Uses and Flows in the European Union. JRC Science for Policy Report. Available online: http://publications.jrc.ec.europa.eu/repository/bitstream/ JRC109869/jrc109869_biomass_report_final2pdf2.pdf (accessed on 21 February 2018).

4. United Nations Framework Convention on Climate Change (UNFCCC). Adoption of the Paris Agreement. Available online: http://unfccc.int/resource/docs/2015/cop21/eng/109r01.pdf (accessed on 21 February 2018).

5. Schneier, T.; Kaul, C.M.; Pressel, K.G. Possible climate transitions from breakup of stratocumulus decks under greenhouse warming. Nature 2019, 12, 163-167.

6. Lee, A.F.; Bennett, J.A.; Manayil, J.C.; Wilson, K. Heterogeneous catalysis for sustainable biodiesel production via esterification and transesterification. Chem. Soc. Rev. 2014, 43, 7887-7916. [CrossRef] [PubMed]

7. Huber, G.W.; Iborra, S.; Corma, A. Synthesis of transportation fuels from biomass: Chemistry, catalysts, and engineering. Chem. Rev. 2006, 106, 4044-4098. [CrossRef]

8. Serrano-Ruiz, J.C.; Dumesic, J.A. Catalytic routes for the conversion of biomass into liquid hydrocarbon transportation fuels. Energy Environ. Sci. 2011, 4, 83-99. [CrossRef]

9. Carlson, T.R.; Vispute, T.P.; Huber, G.W. Green Gasoline by Catalytic Fast Pyrolysis of Solid Biomass Derived Compounds. ChemSusChem 2008, 1, 397-400. [CrossRef] [PubMed]

10. Kabir, G.; Hameed, B.H. Recent progress on catalytic pyrolysis of lignocellulosic biomass to high-grade bio-oil and bio-chemicals. Renew. Sustain. Energy Rev. 2017, 70, 945-967. [CrossRef]

11. Chen, S.Y.; Mochizuki, T.; Abe, Y.; Toba, M.; Yoshimura, Y. Ti-incorporated SBA-15 mesoporous silica as an efficient and robustLewis solid acid catalyst for the production of high-qualitybiodiesel fuels. Appl. Catal. B Environ. 2014, 148-149, 344-356. [CrossRef]

12. Chen, S.Y.; Lao-ubol, S.; Mochizuki, T.; Abe, Y.; Toba, M.; Yoshimura, Y. Transformation of non-edible vegetable oils into biodiesel fuels catalyzed by unconventional sulfonic acid-functionalized SBA-15. Appl. Catal. A Gen. 2014, 485, 28-39. [CrossRef]

13. Chen, S.Y.; Mochizuki, T.; Abe, Y.; Toba, M.; Yoshimura, Y.; Somwongsa, P.; Lau-ubol, S. Carbonaceous Ti-incorporated SBA-15 with enhanced activity and durability for high-quality biodiesel production: Synthesis and utilization of the P123 template as carbon source. Appl. Catal. B Environ. 2016, 181, 800-809. [CrossRef] 
14. Chen, S.Y.; Attanatho, L.; Chang, A.; Laosombut, T.; Nishi, M.; Mochizuki, T.; Takagi, H.; Yang, C.M.; Abe, Y.; Toba, M.; et al. Profiling and catalytic upgrading of commercial palm oil-derived biodiesel fuels for high-blend fuels. Catal. Today 2018, in press. [CrossRef]

15. Mansir, N.; Taufiq-Yap, Y.H.; Rashid, U.; Lokman, I.M. Investigation of heterogeneous solid acid catalyst performance on low grade feedstocks for biodiesel production: A review. Energy Convers. Manag. 2017, 141, 171-182. [CrossRef]

16. Masoumeh Hajjari, M.; Tabatabaei, M.; Aghbashlo, M.; Ghanavati, H. A review on the prospects of sustainable biodiesel production: A global scenario with an emphasis on waste-oil biodiesel utilization. Renew. Sustain. Energy Rev. 2017, 72, 445-464. [CrossRef]

17. Luterbacher, J.S.; Alonso, D.M.; Dumesic, J.A. Targeted chemical upgrading of lignocellulosic biomass to platform molecules. Green Chem. 2014, 16, 4816-4838. [CrossRef]

18. Mochizuki, T.; Toba, M.; Yoshimura, Y. Fast pyrolysis of Jatropha residues over zeolite catalysts. J. Jpn. Petrol. Inst. 2012, 55, 69-70. [CrossRef]

19. Mochizuki, T.; Toba, M.; Yoshimura, Y. Effect of electrostatic precipitator on collection efficiency of bio-oil in fast pyrolysis of biomass. J. Jpn. Petrol. Inst. 2013, 56, 401-405. [CrossRef]

20. Mochizuki, T.; Chen, S.Y.; Toba, M.; Yoshimura, Y. Pyrolyzer-GC/MS system-based analysis of the effects of zeolite catalysts on the fast pyrolysis of Jatropha husk. Appl. Catal. A Gen. 2013, 456, 174-181. [CrossRef]

21. Mochizuki, T.; Chen, S.Y.; Toba, M.; Yoshimura, Y. Deoxygenation of guaiacol and woody tar over reduced catalysts. Appl. Catal. B Environ. 2014, 146, 237-243. [CrossRef]

22. Mortensena, P.M.; Grunwaldt, J.D.; Jensena, P.A.; Knudsenc, K.G.; Jensena, A.D. A review of catalytic upgrading of bio-oil to engine fuels. Appl. Catal. A Gen. 2011, 407, 1-19. [CrossRef]

23. Yoshimura, Y.; Sato, T.; Shimada, H.; Matsubayashi, N.; Nishijima, A. Influences of oxygen-containing substances on deactivation of sulfided molybdate catalysts. Appl. Catal. 1991, 73, 55-63. [CrossRef]

24. Laurent, E.; Delmon, B. Study of the hydrodeoxygenation of carbonyl, carboxylic and guaiacyl groups over sulfide $\mathrm{CoMo} / \gamma-\mathrm{Al}_{2} \mathrm{O}_{3}$ and $\mathrm{NiMo} / \gamma-\mathrm{Al}_{2} \mathrm{O}_{3}$ catalyst. II. Influence of water, ammonia and hydrogen sulfide. Appl. Catal. A Gen. 1994, 109, 97-115. [CrossRef]

25. Hrabar, A.; Hein, J.; Gutiérrez, O.Y.; Lercher, J.A. Selective poisoning of the direct denitrogenation route in o-propylaniline $\mathrm{HDN}$ by DBT on Mo and $\mathrm{NiMo} / \gamma-\mathrm{Al}_{2} \mathrm{O}_{3}$ sulfide catalysts. J. Catal. 2011, 281, 325-338. [CrossRef]

26. Prins, R.; Egorova, M.; Röthlisberger, A.; Zhao, Y.; Sivasankar, N.; Kukula, P. Mechanisms of hydrodesulfurization and hydrodenitrogenation. Catal. Today 2006, 111, 84-93. [CrossRef]

27. Hiroshima, K.; Mochizuki, T.; Honma, T.; Shimizu, T.; Yamada, M. High HDS activity of Co-Mo/ $\mathrm{Al}_{2} \mathrm{O}_{3}$ modified by some chelates and their surface fine structures. Appl. Sur. Sci. 1997, 121/122, 433-436. [CrossRef]

28. Prins, R.; Zhao, Y.; Sivasankar, N.; Kukula, P. Mechanism of CN bond breaking in hydrodenitrogenation. J. Catal. 2005, 234, 509-512. [CrossRef]

29. Egorova, M.; Prins, R. The role of Ni and Co promoters in the simultaneous HDS of dibenzothiophene and $\mathrm{HDN}$ of amines over $\mathrm{Mo} / \gamma-\mathrm{Al}_{2} \mathrm{O}_{3}$ catalysts. J. Catal. 2006, 241, 162-172. [CrossRef]

30. Chen, S.Y.; Nishi, M.; Mochizuki, T.; Takagi, H.; Takatsuki, A.; Roschat, W.; Toba, M.; Yoshimura, Y. Co-processing of Jatropha-derived bio-oil with petroleum distillates over mesoporous CoMo and NiMo sulfide catalysts. Catalysts 2018, 8, 59. [CrossRef]

31. Toba, M.; Abe, Y.; Kuramochi, H.; Osako, M.; Mochizuki, T.; Yoshimura, Y. Hydrodeoxygenation of waste vegetable oil over sulfide catalysts. Catal. Today 2011, 164, 533-537. [CrossRef]

32. Yoshimura, Y.; Matsubayashi, N.; Sato, T.; Shimada, H.; Nishijima, A. Molybdate catalysts prepared by a novel impregnation method: Effect of citric acid as a ligand on the catalytic activities. Appl. Catal. A. Gen. 1991, 79, 145-159. [CrossRef]

33. Yoshimura, Y.; Toba, M.; Matsubayashi, N.; Matsui, T. Hydrotreating Catalyst of Catalytic Cracking Gasoline. U.S. Patent US7393807 B2, 1 July 2008.

34. Kwon, D.; Ko, M.S.; Yang, J.S.; Kwon, M.J.; Lee, S.-W.; Lee, S. Identification of refined petroleum products in contaminated soils using an identification index for GC chromatograms. Environ. Sci. Pollut. Res. 2015, 22, 12029-12034. [CrossRef]

35. The JIS K2249 Method, Petroleum Products—Determination of Distillation Characteristics. Available online: http://kikakurui.com/k2/K2254-2018-01.html (accessed on 12 December 2018). 
36. The K2280-5 Method, Petroleum Products-Fuels—Determination of Octane Number, Cetane Number and Calculation of Cetane Index. Available online: http://kikakurui.com/k2/K2280-5-2013-01.html (accessed on 20 November 2013).

37. Kouzu, M.; Kuriki, Y.; Uchida, K.; Sakanishi, K.; Sugimoto, Y.; Saito, I.; Fujii, D.; Hirona, K. Catalytic hydrotreating of petroleum residue over carbon-supported nickel-molybdenum sulfides. Energy Fuels 2005, 19, 725-730. [CrossRef] 